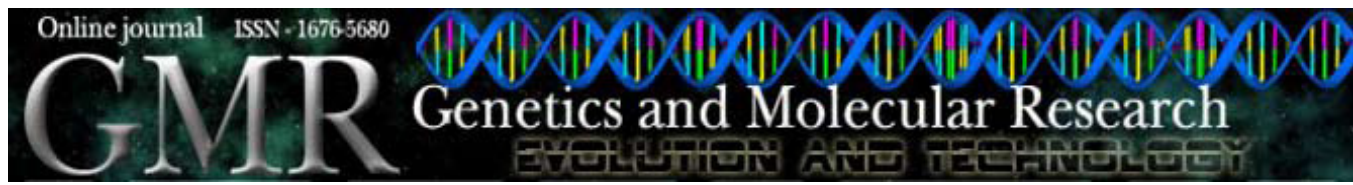

Short Communication

\title{
Sequence analysis of the growth hormone gene of the South American catfish Rhamdia quelen
}

\author{
B.S. Vaz ${ }^{1}$, G.M. Cerqueira ${ }^{2,4}$, J.C. Silva ${ }^{1}$, V.H.B. Manzke ${ }^{3}$, C.G.A. Moreira ${ }^{1}$ \\ and H.L.M. Moreira ${ }^{1}$ \\ 'Laboratório de Engenharia Genética Animal, Centro de Biotecnologia, \\ Universidade Federal de Pelotas, Pelotas, RS, Brasil \\ ${ }^{2}$ Laboratório de Biologia Molecular, Centro de Biotecnologia, Universidade \\ Federal de Pelotas, Pelotas, RS, Brasil \\ ${ }^{3}$ Conjunto Agrotécnico Visconde da Graça, Pelotas, RS, Brasil \\ ${ }^{4}$ Centro de Biotecnologia, Instituto Butantan, São Paulo, SP, Brasil \\ Corresponding author: H.L.M. Moreira \\ E-mail: heden.luiz@gmail.com
}

Genet. Mol. Res. 9 (4): 2184-2190 (2010)

Received December 6, 2009

Accepted April 14, 2010

Published November 9, 2010

DOI 10.4238/vol9-4gmr708

\begin{abstract}
Rhamdia quelen is an important Neotropical catfish species for fisheries and aquaculture in southern Brazil, where it is called Jandia. Like other native Brazilian species of economic importance, $R$. quelen genetics needs more attention for animal breeding programs. The growth hormone gene is known to be linked to a number of molecular markers and quantitative trait loci. We sequenced the coding region of the growth hormone gene with the primer walking technique. As in other Siluriformes, the $R$. quelen growth hormone gene has four introns and five exons, in a 1465-bp coding region. The tertiary structure of the encoded protein was predicted by bioinformatics; it has four $\alpha$-helix structures connected by loops, which form a compressed complex maintained by two disulfide bridges.
\end{abstract}

Key words: Rhamdia quelen; Siluriformes; Growth hormone;

Bioinformatics; Primer walking 
Jundia (Rhamdia quelen) is a Neotropical catfish that shows a high potential for aquaculture in Rio Grande do Sul State, Southern Brazil (Baldisserotto, 2009), due to an elevated growth rate, good carcass yield, and easy reproductive handling under the subtropical climate (Gomes et al., 2000; Francalossi et al., 2004; de Amorin et al., 2009). Jundia is the most commercialized native species in Rio Grande do Sul State (750 tons/year) (Boscardin, 2008; Baldisserotto, 2009), and 50\% is supplied from aquaculture and 50\% from artisanal fishery, corresponding to an annual amount of U\$882,800. Rio Grande do Sul and Santa Catarina States are the only ones that significantly explore the Jundia fishery stocks, as revealed by the annual fishery statistics from the Brazilian government (IBAMA, 2008). Despite vast knowledge about this species, molecular genetics of Jundia requires more attention since it may provide useful information to support animal breeding programs, genetic conservation and understanding of phylogeny (Gomes et al., 2000).

Growth hormone $(\mathrm{GH})$ is synthesized in the somatotrophic axis and is phenotypically associated with characteristics of interest to animal breeding, such as growth, reproduction (Duan, 1998; Gomez et al., 1998) and osmoregulation (Mccormik, 2001). In addition, growth hormone may be the most promising growth-promoting agent in aquaculture (Zohar, 1989), since it is essential for somatic growth and reproduction in bony fishes and osmoregulation in euryhaline fishes (Sciara et al., 2006). Among vertebrates, GH is essential for normal growth and is involved in the regulation of several anabolic processes (Xu et al., 2001).

The teleost $g h$ genes can be grouped into two types: on the one hand are genes of the Siluriforms and Cypriniforms, which consist of five exons and four introns (5-exon type), and on the other hand are those of the Salmoniforms, Perciforms, and Tetradontiforms, which consist of six exons and five introns (6-exon type). Structurally, the latter differs from the former by the presence of an intron inserted in the 5th exon (Moriyama et al., 2006). The $g h$ gene has been shown to serve as a natural marker for studies of evolutionary genetics of various fishes because of its sequence conservation, sufficient length and minimal amount of homoplasy (Marins et al., 2003; Chen et al., 2004; Pinheiro et al., 2008). The aim of this study was to annotate the coding sequence of the $R$. quelen $g h$ gene and perform a $g h$-based phylogenetic analysis within the Siluriformes family.

Primers were designed by the use of the Vector NTi 10.0 software (Invitrogen), and they were based on the alignment of the several $g h$ gene sequences from the diverse Siluriformes species available in GenBank. The sequences were aligned in the Align-X software (Invitrogen). The degenerated primers used for polymerase chain reaction (PCR) amplification correspond to GH_forward: 5'-GCARAAATGGCTMGAGGTAAGG-3' and GH_reverse: 5'-CARRGTGCAGTTGGAATCC-3', while those employed in the primer walking method correspond to GH forward2: 5'-TTACCAGAAGAACGCAAACAGC-3', GH forward3: 5'-GCACAATTTCAATCCTCACCAG-3', GH_reverse2: 5'-CACTGTCAAAGAAGAAAA GAGGTAG-3', and GH_reverse3: 5'-ATCAGGCGGTAGGAAGTGTGC-3'. The gh gene was amplified by PCR as follows: $94^{\circ} \mathrm{C}$ for $3 \mathrm{~min}, 35$ cycles of $94^{\circ} \mathrm{C}$ for $30 \mathrm{~s}, 55^{\circ} \mathrm{C}$ for $30 \mathrm{~s}$ and $72^{\circ} \mathrm{C}$ for $2 \mathrm{~min}$, and a final extension step of $72^{\circ} \mathrm{C}$ for $7 \mathrm{~min}$. The products were amplified by the use of Taq DNA Polymerase (Invitrogen), and amplification was confirmed by agarose gel electrophoresis. The PCR product was purified by adding one volume of $20 \%$ polyethylene glycol and $2.5 \mathrm{M} \mathrm{NaCl}$. The solution was incubated at $37^{\circ} \mathrm{C}$ for $1 \mathrm{~h}$ and centrifuged at 16,000 $g$ for $1 \mathrm{~h}$ at room temperature. The supernatant was removed and $125 \mu \mathrm{L}$ cold $80 \%$ ethanol was added to the microtube. The material was centrifuged for $10 \mathrm{~min}$ at room temperature 
at $16,000 \mathrm{~g}$ and the supernatant was removed. Again, $125 \mu \mathrm{L}$ cold $80 \%$ ethanol was added and immediately removed. The microtube was incubated at $37^{\circ} \mathrm{C}$ until complete evaporation of the ethanol. Sequencing was performed in a MegaBACE 500 DNA sequencer (GEHealthcare) by the use of the Dyenamic ET-terminator technology. Contigs were assembled using the ContigExpress software (Invitrogen). The assembled sequence was submitted to BLAST alignment analysis (www.ncbi.nlm.nih.gov/BLAST) for confirmation. The $R$. quelen gh gene sequence was deposited in GenBank under accession No. EF101341. The Genescan software was used for the annotation of the exon/intron regions of the $g h$ gene sequence. In silico translation and protein analysis were performed by the use of the Vector NTi 10.0 software (Invitrogen). The phylogenetic analysis was performed with the use of the Mega 4.1 software (Grisoft). The neighbor-joining method using the p-distance model was applied, and a bootstrap value of 1000 replications was used for the inference of the tree structure. The tertiary structure of GH was predicted on Poseidon Linux platform (Ferreira et al., 2009) using Modeller (Eswar et al., 2003), employing a homology prediction analysis (Lambert et al., 2002), and the protein structure was visualized with the use of PyMOL (DeLano, 2002).

Initially, six animals, which were maintained in the same breeding tank, were randomly selected for chromosomal DNA extraction. Since there are no known $R$. quelen gh sequences, several other $g h$ entries in GenBank, from different bony fish species, were aligned for identification of conserved sites for primer design. Primer degeneracy was employed to ensure hybridization. The coding region of the $R$. quelen $g h$ gene was amplified by PCR from the six different animals, but only one was selected for further sequencing. As expected, all individuals showed the same amplification pattern, with bands of approximately $1500 \mathrm{bp}$ in length. The PCR product was directly sequenced without any cloning steps, in order to avoid the occurrence of point mutations that could provide incorrect information. Primer walking was necessary to close gaps in the $R$. quelen gh gene sequence. By in silico analysis, the partial $R$. quelen gh gene sequence was determined to have $1565 \mathrm{bp}$, thus distributed as six introns and five exons (exon nucleotide positions range from 1 to 10,209 to 348,438 to 554 , 1038 to 1169 , and 1254 to 1457 , based on GenBank accession No. EF101341). The predicted mRNA sequence contains 603 nucleotides and encodes a protein of $22 \mathrm{kDa}$.

The extent of $g h$ identity was evaluated among all bony fishes. For this purpose, the few sequences available in GenBank were used for global alignment, including that from $R$. quelen $g h$ (Table 1). A clear evidence of sequence heterogeneity was found at the nucleotide level. Point mutations were evenly distributed, but, interestingly, gaps were found occupying mostly the 3'end portion of the gh genes. Amino acid substitutions showed a higher number of non-synonymous mutations within the carboxy-terminal portion of the GH protein. This suggests that selection pressure possibly contributed to environmental adaptation rather than species evolution. The coding sequences of the $g h$ gene were used for phylogenetic analysis. As expected, within the assembled tree, three major clusters can be observed containing the Cypriniformes, Salmoniformes and Siluriformes species. Rhamdia quelen is positioned within the Siluriformes group, and based on the $g h$ gene sequences analysis, it appears to be the most ancient in relation to the other species (Figure 1).

In silico analysis of the three-dimensional structure of $R$. quelen $\mathrm{GH}$ demonstrated the presence of four $\alpha$-helices connected by loops, which form a compressed complex maintained by covalent bonds of two disulfide bridges between amino acids Cys61 and 


\begin{tabular}{|c|c|c|}
\hline Species & Length (bp) & Accession Nos. \\
\hline Carassius aurata & $633^{+}$ & DQ350437 \\
\hline Carassius cuvieri & $633^{+}$ & AF389237 \\
\hline Catla catla & $894^{+}$ & AY053361 \\
\hline Cirrhinus mrigala & $1150^{+}$ & AF140281 \\
\hline Clarias batrachus & $663^{+}$ & AF416485 \\
\hline Clarias gariepinus & $1456^{*}$ & AF416488 \\
\hline Coregonus autumnalis & $742^{+}$ & X77245 \\
\hline Ctenopharyngodon idella & $1171^{+}$ & X60474 \\
\hline Cyprinus carpio & $1164^{+}$ & M27000 \\
\hline Danio rerio & $1270^{*}$ & NM_001020492 \\
\hline Gymnocypris przewalskii & $771^{+}$ & AY707317 \\
\hline Heteropneustes fossilis & $1132^{+}$ & AF147792 \\
\hline Hypophthalmichthys molitrix & $1170^{+}$ & X60475 \\
\hline Hypophthalmichthys nobilis & $1158^{+}$ & S60473 \\
\hline Ictalurus punctatus & $3379 *$ & AF267989 \\
\hline Ictiobus bubalus & $1279^{+}$ & AY375301 \\
\hline Labeo bata & $896^{+}$ & AY691180 \\
\hline Labeo fimbriatus & $893^{+}$ & AY691182 \\
\hline Labeo gonius & $894^{+}$ & AY691183 \\
\hline Labeo kontius & $895^{+}$ & AY691184 \\
\hline Labeo rohita & $885^{+}$ & AF416490 \\
\hline Megalobrama amblycephala & $1170^{+}$ & AY170124 \\
\hline Misgurnus anguillicaudatus & $1154^{+}$ & AY334554 \\
\hline Misgurnus mizolepis & $5099 *$ & AF133815 \\
\hline Morulius calbasu & $894^{+}$ & AY691181 \\
\hline Mylopharyngodon piceus & $633^{+}$ & AF389238 \\
\hline Myxocyprinus asiaticus & $633^{+}$ & DQ350434 \\
\hline Oncorhynchus keta & $1120^{+}$ & $\mathrm{X} 17593$ \\
\hline Oncorhynchus masou & $1176^{+}$ & X59762 \\
\hline Oncorhynchus tshawytscha & $1138^{+}$ & S50867 \\
\hline Pangasianodon gigas & $1176^{+}$ & L27835 \\
\hline Pangasius pangasius & $603^{+}$ & M63713 \\
\hline Paramisgurnus dabryanus & $633^{+}$ & DQ350432 \\
\hline Pelteobagrus fulvidraco & $603^{+}$ & DQ112163 \\
\hline Pimephales promelas & $1122^{+}$ & AY643399 \\
\hline Rhamdia quelen & $1465^{*}$ & EF101341 \\
\hline Salmo salar & $4397 *$ & M21573 \\
\hline Silurus asotus & $1082^{+}$ & AY157496 \\
\hline Silurus meridionalis & $602^{+}$ & AF530481 \\
\hline
\end{tabular}

${ }^{+}$Corresponds to the mRNA. *Corresponds to the full-length gene without the regulatory region.

Cys163, and Cys188 and Cys180. Despite their close genetic relationship, Siluriformes, Salmoniformes and Cypriniformes show structural peculiarities with regard to GH. For example, Siluriformes GH is 10 amino acids shorter (200 amino acids) than that of Cypriniformes and Salmoniformes, although all three groups bear the same number of introns and exons in their respective $g h$ genes (Figure 2).

In this study, we sequenced and characterized the $g h$ gene from $R$. quelen, and its encoded GH protein. Additionally, we used the $g h$ sequences from a number of bony fish species to infer their genetic relatedness and found that $R$. quelen occupies an ancient position within the Siluriformes group. Our results provide useful information for further studies on the $R$. quelen breeding and add to the previous knowledge of bony fish phylogeny. Further studies employing the $R$. quelen $g h$ sequence are encouraged in the several fields of fish studies. 


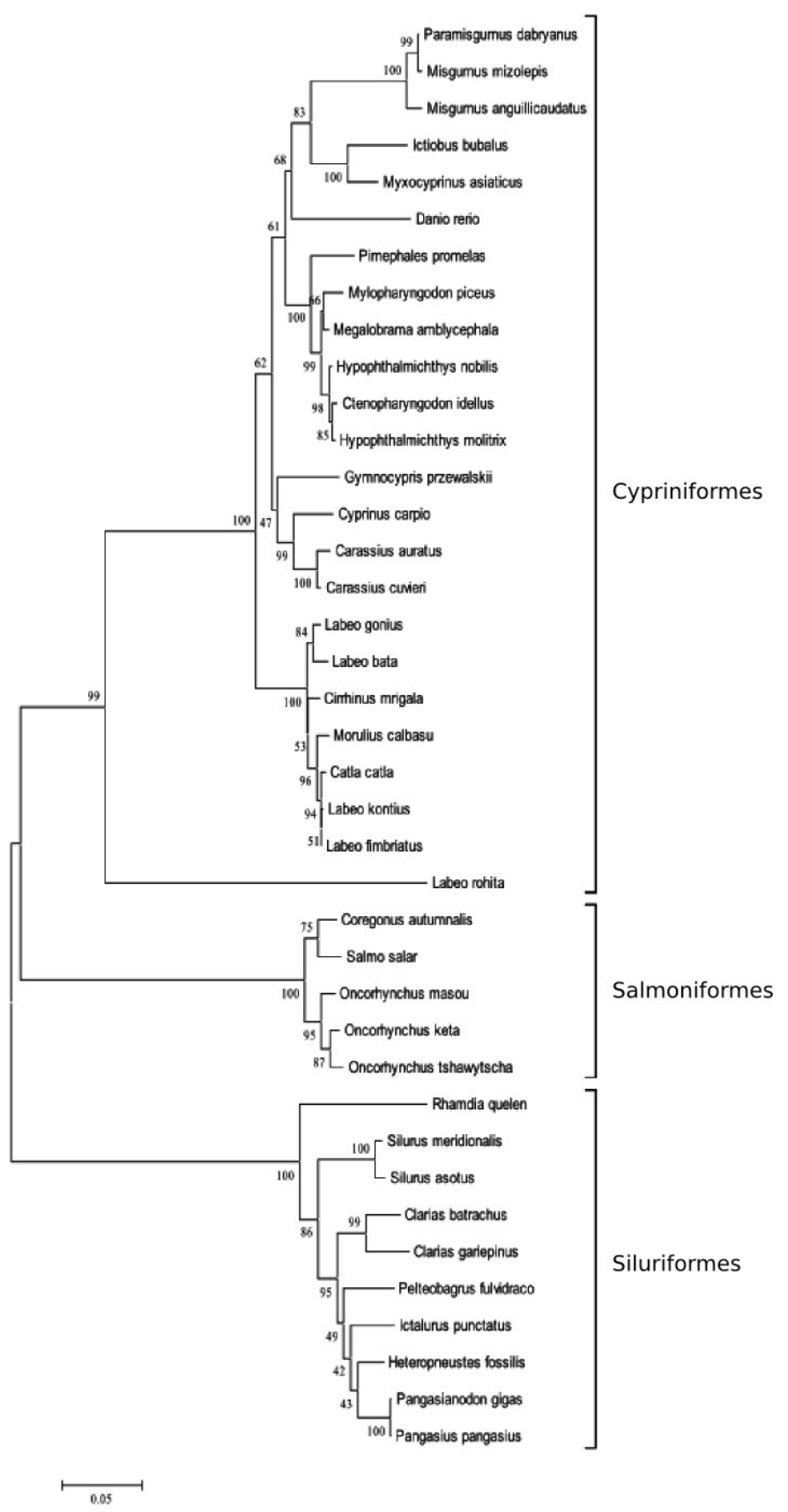

Figure 1. Unrooted phylogenetic tree was constructed based on the $g h$ gene sequences ( $>600 \mathrm{bp}$ ), and it demonstrates the genetic relationship among the bony fish species. The tree was constructed by the neighbor-joining method employing the p-distance model. Bootstrap consensus values are indicated in the nodes. The use of one thousand replications was chosen for tree construction. 


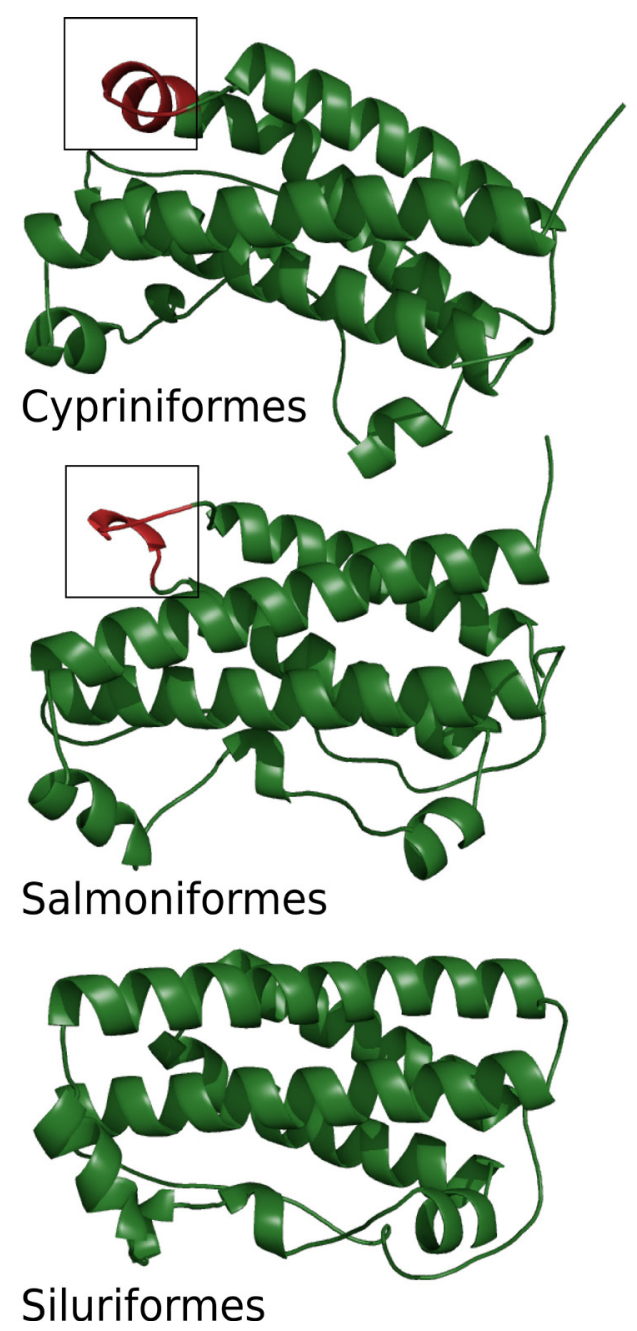

Figure 2. Three-dimensional model of the growth hormone from Cypriniformes, Salmoniformes and Siluriformes. Modeling was performed by homology search analysis. In detail is the additional 10-amino acid structure.

\section{ACKNOWLEDGMENTS}

B.S. Vaz, G.M. Cerqueira and J.C. Silva were supported by CAPES foundation, Brazilian Ministry of Education. Research supported by CNPq grant, Brazilian Ministry of Science and Technology.

\section{REFERENCES}

Baldisserotto B (2009). Freshwater fish culture in Rio Grande do Sul State: actual situation, problems and future perspectives. Cienc. Rural 39: 291-299.

Boscardin NR (2008). A Produção Aqüicola Brasileira. In: Aqüicultura no Brasil: o Desafio é Crescer (Ostrensky A and 
Borghetti D Jr, eds.). Secretaria Especial de Aqüicultura e Pesca/FAO, Brasília, 27-72.

Chen Y, Wang Y, He S and Zhu Z (2004). Cloning and sequencing of the growth hormone gene of large yellow croaker and its phylogenetic significance. Biochem. Genet. 42: 365-375.

de Amorin MP, Gomes BVC, Martins YS, Sato Y, et al. (2009). Early development of the silver catfish Rhamdia quelen (Quoy \& Gaimard, 1824) (Pisces: Heptapteridae) from the São Francisco River Basin, Brazil. Aquac. Res. 40: 172180.

DeLano WL (2002). Pymol: An open-source molecular graphics tool. In: CCP4. Newsl. Protein Crystallogr. 40: 44-53.

Duan C (1998). Nutritional and developmental regulation of insulin-like growth factors in fish. J. Nutr. 128: 306S-314S.

Eswar N, John B, Mirkovic N, Fiser A, et al. (2003). Tools for comparative protein structure modeling and analysis. Nucleic Acids Res. 31: 3375-3380.

Ferreira CS, Vaz BS, Velasco G, Tavares RA, et al. (2009). Poseidon Linux 3.x - The Scientific GNU/Linux option. Panamjas 4: I-VI.

Fracalossi DM, Meyer G, Weingartner M, Santamaria FM, et al. (2004). Desempenho do jundiá, Rhamdia quelen, e do dourado, Salminus brasiliensis, em viveiros de terra na região sul do Brasil. Acta Sci. Anim. Sci. 26: 345-352.

Gomes LC, Golombieski JI and Gomes ARC (2000). Biology of Rhamdia quelen (Teleostei, Pemelodidae). Cienc. Rural 30: $179-185$.

Gomez JM, Loir M and Le Gac F (1998). Growth hormone receptors in testis and liver during the spermatogenetic cycle in rainbow trout (Oncorhynchus mykiss). Biol. Reprod. 58: 483-491.

IBAMA (Instituto Brasileiro do Meio Ambiente) (2008). Estatística da Pesca 2006 Brasil: Grandes Regiões e Unidades da Federação. IBAMA, Brasília.

Lambert C, Leonard N, De Bolle X, and Depiereux E (2002). ESyPred3D: Prediction of proteins 3D structures. Bioinformatics 18: 1250-1256.

Marins L, Levy J, Folch J and Sanchez A (2003). A growth hormone-based phylogenetic analysis of euteleostean fishes including a representative species of the Atheriniformes Order, Odontesthes argentinensis. Genet. Mol. Biol. 26: 295-300.

McCormick SD (2001). Endocrine control of osmoregulation in teleost fish. Am. Zool. 41: 781-794.

Moriyama S, Oda M, Takahashi A, Sower SA, et al. (2006). Genomic structure of the sea lamprey growth hormoneencoding gene. Gen. Comp. Endocrinol. 148: 33-40.

Pinheiro JS, Wolff J, Araújo R and Hilsdorf A (2008). Molecular cloning and sequence analysis of growth hormone cDNA of Neotropical freshwater fish Pacu (Piaractus mesopotamicus). Genet. Mol. Biol. 31: 381-384.

Sciara AA, Rubiolo JA, Somoza GM and Arranz SE (2006). Molecular cloning, expression and immunological characterization of pejerrey (Odontesthes bonariensis) growth hormone. Comp. Biochem. Physiol. C. Toxicol. Pharmacol. 142: 284-292.

Xu B, Moriyama S, Zhang PJ, Miao HZ, et al. (2001). The complete amino acid sequence of growth hormone and partial amino acid sequence of prolactin and somatolactin from sea perch (Lateolabrax japonicus). Aquaculture 201: 117136.

Zohar Y (1989). Endocrinology and fish farming: Aspects in reproduction, growth, and smoltification. Fish Physiol. Biochem. 7: 395-405. 